\title{
RELATIVE EFFECTIVENESS OF GREEN AND RED APPLE JUICE ON REDUCING CHOLESTEROL LEVELS AMONG PATIENTS WITH HYPERCHOLESTEROLEMIA
}

\author{
Hasneli, Safyanti, Fahyu Widia \\ School of Health Polytechnics, Ministry of Health Padang
}

\begin{abstract}
Background: Epidemiological studies have indicated possible relationships between diet and various chronic diseases, including hypercholesterolemia. Positive effects of fruits and vegetables have been attributed to dietary fibers, antioxidants, and especially phenolic compounds. Hypercholesterolemia is a metabolic disorder characterized by high level of cholesterol in the blood ( $\geq 200 \mathrm{mg} / \mathrm{dl}$ ). Apples have fiber and chemical components such as flavonoids, polyphenols, and carotenoids, which are capable of improving the lipid profile. This study aimed to examine relative effectiveness of green and red apple juice on reducing cholesterol levels among patients with hypercholesterolemia.

Subjects and Method: This was a quasi experiment study with pre and post test design conducted in Health Laboratory of Padang, from November 2016 to June 2017. A sample of 14 patients with hypercholesterolemia aged age $35-65$ years old was selected for this study. The dependent variable was cholesterol level. The independent variable was green and red apple juice administration. Green and red apple juice was given for 7 consecutive days. Data on total cholesterol level were measured by blood examination. The data were analyzed by t-test.

Results: Mean difference of total cholesterol level before and after in the green apple juice group $(62.3 \mathrm{mg} / \mathrm{dL}$ ) was larger than in the red apple juice group $(13.9 \mathrm{mg} / \mathrm{dL})$, and it was statistically significant $(\mathrm{p}=0.032)$.

Conclusion: Green apple juice is more effective than red apple juice to reduce total cholesterol level among patients with hypercholesterolemia.
\end{abstract}

Keywords: total cholesterol, green apple juice, red apple juice, patients with hypercholesterolemia

\section{Correspondence:}

Hasneli. School of Health Polytechnics, Ministry of Health Padang.

Email: hasneli.darwis@yahoo.com. Mobile: +82284141034.

The 5th International Conference on Public Health

Best Western Premier Hotel, Solo, Indonesia, February 13-14, 2019 | 672

https://doi.org/10.26911/theicph.2019.05.28 